\title{
Combining Wind and Solar Energy to Meet Demands in Somali Region of Ethiopia (A Case of Dembel District)
}

\author{
Natei Ermias Benti \\ College of Natural and Computational Sciences, Center for Environmental Science, Addis Ababa University, Addis Ababa, Ethiopia
}

\section{Email address:}

natei.ermias@aau.edu.et

\section{To cite this article:}

Natei Ermias Benti. Combining Wind and Solar Energy to Meet Demands in Somali Region of Ethiopia (A Case of Dembel District). American Journal of Modern Energy. Vol. 3, No. 4, 2017, pp. 73-83. doi: 10.11648/j.ajme.20170304.13

Received: May 13, 2017; Accepted: May 31, 2017; Published: July 25, 2017

\begin{abstract}
Shortage of electric power is a serious problem in Ethiopia. The population living in urban and semi urban areas connected to the national grid makes only less than $20 \%$ of the total. The remaining $80 \%$ of the population in scattered rural villages and have very remote chance to get electricity from the grid. The only realistic approach to electrify the rural areas seems therefore to be the off grid system. Study was conducted to assess suitability of stand-alone wind-solar PV hybrid power for Debmel village which is detached off the main grid line. The data required for this work (wind speed and sunshine hours) were obtained from the National Meteorological Agency (NMA) and analyzed using HOMER \& MATLAB software's. The actual data used was from Dire-Dawa station, which is the closest meteorological station to the village. Both wind power and solar PV power potentials were evaluated from wind speed and sunshine hours of the station, respectively. The electrical load for a model community is considered and a community school together with a health post is included. For the feasibility study of the hybrid system HOMOR is used. By running the software the optimization results have been generated and arranged according to their least net present cost. Furthermore, a sensitivity analysis also carried out for the major sensitivity components of the hybrid system (like PV price, hub height and diesel price). The study revealed that the area has abundant solar energy potential $\left(6.12 \mathrm{KWh} / \mathrm{m}^{2} /\right.$ day $)$ but its wind potential is not as promising. This is partly attributed to the level at which wind speed measurement was taken, $2 \mathrm{~m}$, instead of the recommended $10 \mathrm{~m}$ height. The result of the software shows that the most cost effective system, i.e. the system with the lowest net present cost, is the PV-generator-battery-converter setup. For this set-up, the total net present cost (NPC) is $\$ 155,875$, the cost of energy (COE) is $0.415 \$ / \mathrm{kWh}$, contribution from renewable resources is $91 \%$.
\end{abstract}

Keywords: Solar PV, Sunshine Hours, Wind Power, Wind-Solar PV Hybrid Power, Wind Speed

\section{Introduction}

In developing countries and less developed countries, a significant proportion of the population lives without usable electrical power. Ethiopia is one of developing countries with more than $80 \%$ of its population live without usable electricity [1, 2]. The development of many rural communities has been limitation due to the lack of usable electricity. The more noticeable benefits of usable electric power include: improved health care, improved education, better transportation systems, improved communication systems, a higher standard of living, and economic stability. Unfortunately, many of the rural areas of Ethiopia have not benefited from these uses of electricity. Due to the remote location and the low population densities of the rural communities the traditional means of providing power has proven too expensive, undependable, difficult to maintain, and economically unjustifiable. Consequently, many of these communities remain without electricity and may never receive grid power from the utility [3]. Ethiopia has huge utilizable solar and wind energy potentials convenient for rural electrification [1, 4-6]. It is conceivable that a hybrid system has the advantage of improved reliability and therefore gives better energy service when compared to any particular (wind, solar, etc.) type of stand-alone supply system.

The small town of Dembel and surrounding communities $\left(9^{\circ} 50^{\prime} \mathrm{N} 42^{\circ} 30^{\prime} \mathrm{E} / 9.833^{\circ} \mathrm{N} 42.500^{\circ} \mathrm{E}\right)$ are one of those rural areas which have no access to electricity. Dembel is one of the woredas in the Somali Region of Ethiopia, Part of the Shinile Zone, Dembel is bordered on the west by Shinile, on 
the north by Ayesha, and on the east and south by the Jijiga Zone. Towns in Dembel include Arebi, Biyo Behay, Dembel, Dure, Harmukale, and Smekeb. According to 2004 World Bank memorandum, none of the inhabitants of Dembel have access to electricity.

The remote location and the small size of these towns made it impractical to electrify with grid power system. The community with health clinic and School requires electricity for lighting, refrigeration, medical tools, communication equipment, and etc.

A hybrid solar PV-wind power generation system is proposed to supply electricity to Dembel community to power clinic and school. The Hybrid Renewable Power Generation System (HRPGS) is a system aimed at the production and utilization of the electrical energy coming from more than one source, provided that at least one of them is renewable [7]. Such a system often includes some kind of storage in order to satisfy the demand during the periods in which the renewable sources are not available and to decrease the time shift between the peak load and the maximum power produced and power conditioning unit and controller to convert and control one form of energy to other $[3,8]$.

The aim of this paper is to study solar PV- wind energy system for electrification of rural area of Somali region which not electrified via national grid system. The people in this village use kerosene for lamp, diesel for water pumping and grinding machines, fire wood for cooking and dry cells for radio and tape recorders. Desertification of the land is getting worse and worse due to deforestation and backward agriculture. Thus, in this work a hybrid renewable power generation system integrating these vast solar and wind resources were designed and modeled, to electrify the small town of Dembel and surrounding communities.

\section{Materials and Methods}

A Hybrid study of solar PV and wind power system which comprises of PV arrays and wind turbine with battery banks and power conditioning units and diesel generator has been discussed. Before the study was conducted to design hybrid energy systems of solar PV and wind power system for Shinile Zone of the Ethiopian Somali Regional State, energy consumption, solar energy potentials and wind energy potentials of the area under study had been studied.

\subsection{Energy Demand}

A typical load system for community which lives in Dembel village (Model 100 households) has been considered. As one of the compulsory services for a community, a small clinic a Rural Health Clinic (RHC) is provided. The purpose of the RHC program is improving access to primary care in underserved rural areas. RHCs are required to provide outpatient primary care services and basic laboratory services such as blood sugar, urine and pregnancy test. One of the major time consuming tasks of rural women is grinding. She has to travel across several miles to the city in search of grinding machines. In solution to this problem, a grinding machine has to be provided and the energy system must be capable of satisfying the demand. In quantifying the school load light bulbs for night school has been assumed. The energy demand of the community is summarized in Table 1.

Table 1. Electricity load.

\begin{tabular}{|c|c|c|c|c|c|c|}
\hline Energy Demands & Appliance & Watt (W) & Total Number & Total Power (KW) & Daily use/hour & Daily Energy (KWh/day) \\
\hline \multirow{4}{*}{ Households } & Lamp 1 (Living room) & 11 & 100 & 1.1 & 4 & 4.4 \\
\hline & Lamp 2 (Kitchen room) & 11 & 100 & 1.1 & 2 & 2.2 \\
\hline & Lamp 3 (Bed room) & 11 & 100 & 1.1 & 5 & 5.5 \\
\hline & 21 " color Television & 60 & 100 & 6 & 2 & 12.0 \\
\hline \multirow{2}{*}{ School } & Light bulb for class & 11 & 7 & 0.077 & 3 & 0.231 \\
\hline & Light bulb for toilet & 11 & 1 & 0.011 & 3 & 0.033 \\
\hline \multirow{3}{*}{ Health post } & Microscopes & 100 & 2 & 0.2 & 8 & 1.6 \\
\hline & Radio & $3 \mathrm{~W}$ VHF & 1 & 0.003 & 8 & 0.024 \\
\hline & Light bulb & 11 & 2 & 0.022 & 8 & 0.176 \\
\hline \multirow{3}{*}{ Small busness } & Grinder & $12 \mathrm{KW}$ & 1 & 12 & 6 & 72 \\
\hline & Small & $1.1 \mathrm{KW}$ & 1 & 1.1 & 2 & 2.2 \\
\hline & Total & & & & & 103.244 \\
\hline
\end{tabular}

\subsection{Solar Radiation Estimations}

To determine the PV electricity generation potential for a particular site, it is important to assess the average total solar radiation received over the year. Unfortunately in most developing countries there is no properly recorded radiation data. What usually available is sunshine duration data.

Ethiopia is one of the developing countries which have no properly recorded solar radiation data and, like many other countries, what is available is sunshine duration data. However, given a knowledge of the number of sunshine hours and local atmospheric conditions, sunshine duration data can be used to estimate monthly average solar radiation, with the help of empirical equation 1 [9].

$$
\overline{\mathrm{H}}=\overline{\mathrm{H}}_{\mathrm{o}}\left(\mathrm{a}+\mathrm{b}\left(\frac{\overline{\mathrm{n}}_{\mathrm{s}}}{\overline{\overline{\mathrm{N}}}_{\mathrm{s}}}\right)\right)
$$

Where: $\overline{\mathrm{H}}$ is monthly averaged daily solar radiation on a 
horizontal surface $\left(\mathrm{MJ} / \mathrm{m}^{2}\right), \bar{H}_{o}$ is monthly average daily extraterrestrial radiation on a horizontal surface $\left(\mathrm{MJ} / \mathrm{m}^{2}\right)$, $\bar{n}_{s}$ is a monthly average daily hour of bright sunshine, $\bar{N}_{s}$ is monthly average of the maximum possible daily hours of bright sunshine and $\mathrm{a}$ and $\mathrm{b}$ are regression coefficients

Solar radiation, known as extraterrestrial radiation, $\mathrm{H}_{0}$, on a horizontal plane outside the atmosphere, is given by equation 2 .

$$
H_{o}=\frac{24 * 3600}{\pi} G_{s c}\left[1+0.034 \cos \left(\frac{360 * n_{d}}{365}\right)\right] *\left[\cos \varphi \cos \delta \sin \omega_{s}+\left(\frac{\pi \omega_{s}}{180}\right) \sin \varphi \sin \delta\right]
$$

Where: $\mathrm{n}_{\mathrm{d}}$ is the day number, $\mathrm{G}_{\mathrm{sc}}$ is the solar constant $\left(1368 \mathrm{~W} / \mathrm{m}^{2}\right), \phi$ is the latitude of the location $\left(^{0}\right), \delta$ is the declination angle $\left({ }^{0}\right)$, which is given as follows:[9]

$$
\delta=23.45 * \sin \left(360 * \frac{284+n_{d}}{365}\right)
$$

The solar hour angle is the angular displacement of the sun east or west of the local meridian; morning negative, afternoon positive. The solar hour angle is equal to zero at solar noon and varies by 15 degrees per hour from solar noon. The relation between these angles is given as

$$
\omega=\left(1 t_{L}-12\right) 15^{0}
$$

where $t_{L}=$ local solar time in hours and $\omega=$ solar hour angle $\left.{ }^{0}\right)$

The sunset hour angle $\omega_{s}$ is the solar hour angle corresponding to the time when the sun sets and it is given by

$$
\omega_{s}=\operatorname{Cos}^{-1}(-\tan \varphi \tan \delta)
$$

The day length, $\mathrm{N}_{\mathrm{s}}$, is the maximum possible daily sunshine hour given by

$$
N_{s}=\frac{2}{15} \omega_{s}
$$

The parametric constants (regression constants) $a$ and $b$ are given as [10]

$$
\begin{gathered}
a=-0.110+0.235 \cos \varphi+0.322\left(\frac{\bar{n}_{s}}{\bar{N}_{s}}\right) \\
b=1.449-0.553 \cos \varphi-0.694\left(\frac{\bar{n}_{s}}{\bar{N}_{s}}\right)
\end{gathered}
$$

The longitude \& latitude of the station is taken. Then using equation (3), solar declination is calculated for each day. Then sunshine hour angle is calculated for each day using equation (5). Correspondingly maximum possible sunshine hour $\mathrm{N}_{\mathrm{s}}$ is calculated by equation (6). Extraterrestrial

\begin{tabular}{|c|c|c|c|c|c|c|c|c|c|c|}
\hline Mid of month & $\mathbf{n}_{\mathbf{d}}$ & $\delta\left({ }^{0}\right)$ & $\omega_{\mathrm{s}}\left({ }^{0}\right)$ & $\mathbf{N}_{\mathrm{s}}$ (hrs) & $\mathbf{n}_{\mathbf{s}}$ & $\bar{H}_{o}\left(\mathrm{KWh} / \mathrm{m}^{2} / \mathrm{d}\right)$ & $\mathbf{n}_{\mathbf{s}} / \mathbf{N}_{\mathbf{s}}$ & $\bar{H}\left(\mathrm{KWh} / \mathbf{m}^{2} / \mathbf{d}\right)$ & $\bar{K}_{T}$ & NASA \\
\hline Ja 15 & 15 & -21.3 & 93.9 & 12.5 & 9.3 & 11.29 & 0.7 & 7.34 & 0.6 & 6.09 \\
\hline $\mathrm{Fe} 14$ & 45 & -13.7 & 92.4 & 12.3 & 9.0 & 11.58 & 0.7 & 7.49 & 0.6 & 6.94 \\
\hline Mar 15 & 74 & -2.9 & 90.5 & 12.1 & 8.1 & 11.15 & 0.7 & 7.05 & 0.6 & 6.26 \\
\hline Ap 15 & 105 & 9.3 & 88.3 & 11.8 & 7.9 & 9.77 & 0.7 & 6.18 & 0.6 & 6.18 \\
\hline May 15 & 135 & 18.7 & 86.6 & 11.5 & 8.4 & 8.14 & 0.7 & 5.26 & 0.6 & 6.36 \\
\hline Ju 15 & 166 & 23.3 & 85.7 & 11.4 & 8.3 & 7.07 & 0.7 & 4.57 & 0.6 & 6.04 \\
\hline Jul 15 & 196 & 21.6 & 86.0 & 11.5 & 7.7 & 7.06 & 0.7 & 4.46 & 0.6 & 5.70 \\
\hline Au 15 & 227 & 13.9 & 87.5 & 11.7 & 7.6 & 8.04 & 0.6 & 5.02 & 0.6 & 5.80 \\
\hline Sep 15 & 258 & 2.3 & 89.6 & 11.9 & 7.3 & 9.45 & 0.6 & 5.79 & 0.6 & 5.94 \\
\hline Oc 15 & 288 & -9.5 & 91.7 & 12.2 & 7.9 & 10.46 & 0.6 & 6.53 & 0.6 & 5.94 \\
\hline Nov 15 & 319 & -19.1 & 93.5 & 12.5 & 9.1 & 10.83 & 0.7 & 7.01 & 0.6 & 6.13 \\
\hline Dec 15 & 349 & -23.3 & 94.3 & 12.6 & 9.5 & 10.95 & 0.8 & 7.13 & 0.7 & 6.01 \\
\hline Average & & & & 12.0 & 8.3 & 9.65 & 0.7 & 6.15 & 0.6 & 6.12 \\
\hline
\end{tabular}
radiation $\mathrm{H}_{\mathrm{o}}$ is calculated using equation (2) and then the regression coefficients, $\mathrm{a} \& \mathrm{~b}$ are calculated from the correlation equations presented in equations, (7) and (8). Finally using equations, (1), the solar radiation of the village is estimated (Table 2).

Table 2. Solar energy estimated for Dembel based on Dire Dawa data.

In figure 1 the monthly average daily Global solar radiation for the entire year is depicted. The maximum monthly average daily Global solar radiation occurred between October-March whereas the minimum occurred between June-august. This is as a result of the peak period of the cloud cover in the country due to the rainy season. The result shows that the monthly average daily global solar radiation values for Debmel based on Dire-Dawa data lay between $4.46 \mathrm{KWh} / \mathrm{m}^{2} /$ day (July) and $7.49 \mathrm{KWh} / \mathrm{m}^{2} /$ day (February). The monthly average daily global solar radiation of the site is $6.15 \mathrm{KWh} / \mathrm{m}^{2} /$ day.

\subsection{Wind Resource Data Analysis}

Due to the fact that wind speed data of the Dembel Village area was not available it was decided that Dire Dawa's data should be used instead, which is measured at 2 meter height. In order to utilize these data in calculating and assessing wind energy within the designated location in the site, the first step is to extrapolate the wind speed data collected at $2 \mathrm{~m}$ height to the required height using power law [11]: 


$$
\frac{V}{V_{o}}=\left(\frac{H}{H_{o}}\right)^{\alpha}
$$

Where: $V_{o}$ is wind speed measured at the reference height $\mathrm{H}_{\mathrm{o}}, \mathrm{V}$ is wind speed estimated at height $\mathrm{H}$, and $\alpha$ is ground surface friction coefficient.

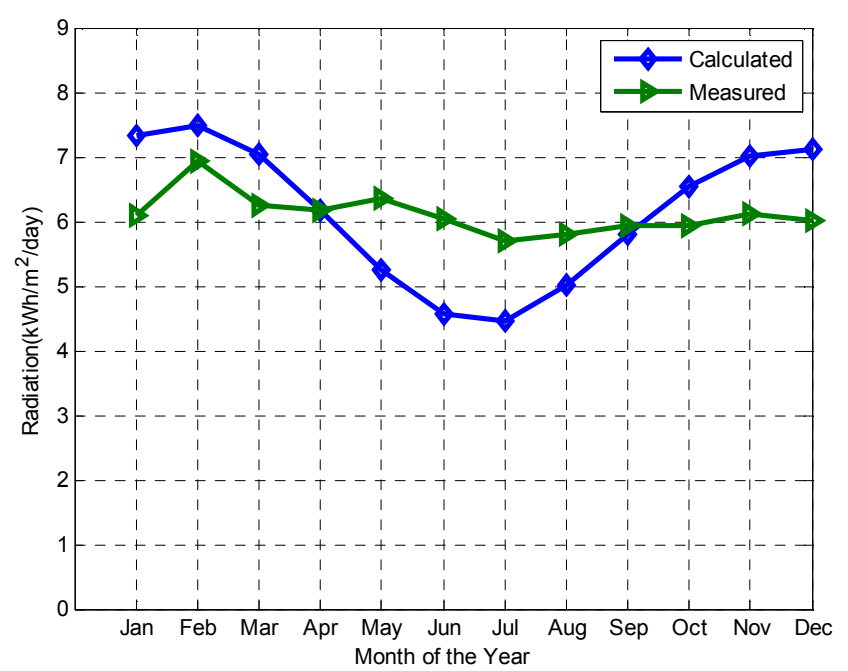

Figure 1. Monthly average daily Global radiations for the entire year (20062014).

The total wind power density, $\mathrm{P} / \mathrm{A}$ is the total available power per unit area, which is given by [12-14]

$$
\frac{P}{A}=\left(\frac{1}{2} \rho \frac{1}{n} \sum V_{i}^{3}\right)
$$

Where: $\mathrm{n}$ is the number of days in a month and $\rho$ is the density of air $\left(1.2 \mathrm{~kg} / \mathrm{m}^{3}\right)$

Before calculating the average wind power density, $\mathrm{v}_{\mathrm{i}}{ }^{3}$ of each day was calculated and the values are summed $\left(\sum \mathrm{v}_{\mathrm{i}}{ }^{3}\right)$, and then divided by the number of days in a month $\frac{1}{n}\left(\sum V_{i}{ }^{3}\right)$.

The data collected at the measured $2 \mathrm{~m}$ height were first extrapolated to 10 meter which is the standard height at which a wind measurement was taken (figure 2) and then extrapolated to the desired height at which the turbine will be installed.

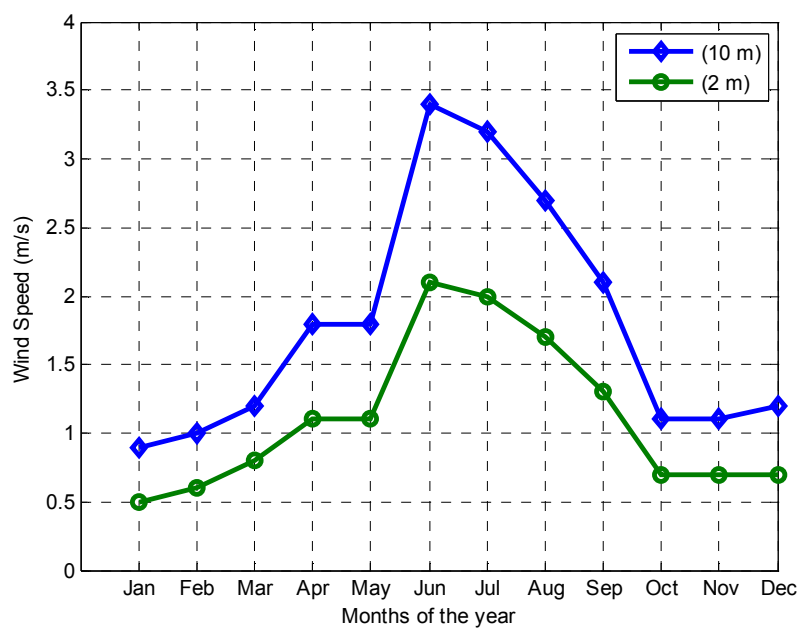

Figure 2. Average wind speeds at $10 \mathrm{~m}$ and $2 \mathrm{~m}$ heights.
The average wind speeds measured at $2 \mathrm{~m}$ are not ideal for estimation of wind speed. Wind speeds at higher heights are larger and the wind forces are higher and hence, the turbine requires more and better structural support (foundation) to ensure the turbines and towers not fall. The maximum turbine height is determined based on the speed of the wind at a given height and the cost that can be allotted per unit power obtained.

For this study the height considered is $30 \mathrm{~m}$ at which the turbine will operate. The monthly wind speed in Dembel after extrapolation from anemometric height to $30 \mathrm{~m}$ for each year are shown in figure 3 , the wind speed varied between $1.2 \mathrm{~m} / \mathrm{s}$ in January and $4.7 \mathrm{~m} / \mathrm{s}$ in June. It can be observed from figure 3 that the windiest months were from June to August with average wind speed of $4.7,4.5$ and $3.7 \mathrm{~m} / \mathrm{s}$, respectively while the calmest month was October with the average wind speed of $1.2 \mathrm{~m} / \mathrm{s}$ for the study period at the extrapolated height of 30 meters. The average wind speed is $2.49 \mathrm{~m} / \mathrm{s}$. Hence, this speed will not be economically viable for wind power generation.

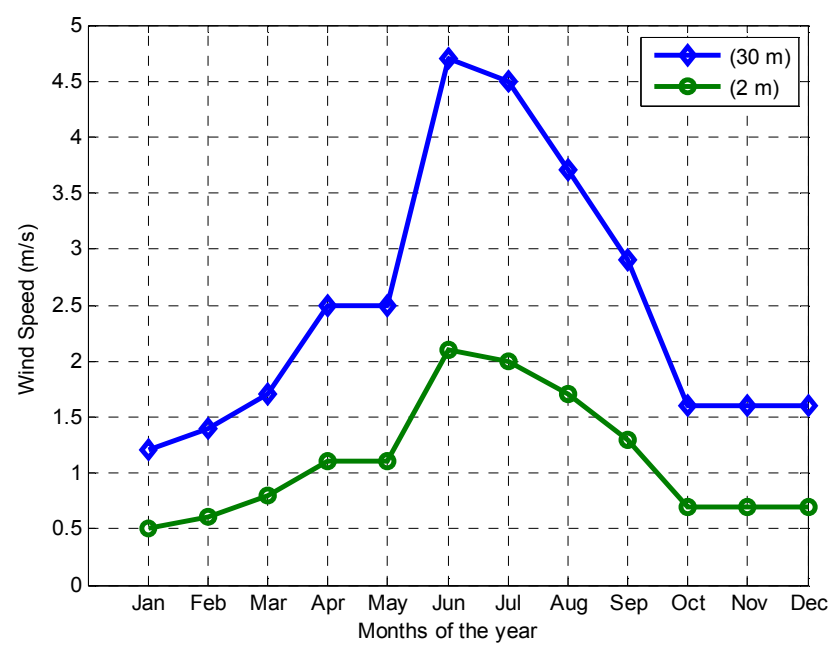

Figure 3. Average wind speeds at $30 \mathrm{~m}$ and $2 \mathrm{~m}$ height.

Then using equation (10), average wind power was calculated for each year at $30 \mathrm{~m}$ (figure 4). The average wind power density shown in figure 4 recorded a similar trend with the average wind speed (figure 3 ). Since wind power density is proportional to the cube of wind speed, a small variation on wind speed will lead to a significant variation in wind power density. Based on the average power density, the maximum occurred during the moth August with a peak of $224.5 \mathrm{~W} / \mathrm{m}^{2}$. The power decreased from September to May with minimum of $1.0 \mathrm{~W} / \mathrm{m}^{2}$ in January. The average wind power density of the village is calculated as $39.4 \mathrm{~W} / \mathrm{m}^{2}$. According to International American wind power classification, the site under study falls under class 1 (poor resource).

\section{Design of Hybrid Power Generation System}

A hybrid system is a combination of one or more resources 
of renewable energy such as solar, wind, micro/minihydropower and biomass with other technologies such as batteries and diesel generator [8, 15-30]. The hybrid system studied in this work is one combining solar PV and wind turbine with diesel generator(s) and bank of batteries, which are included for backup purposes. Power conditioning units, such as inverters, are also part of the supply system. Hybrid wind turbine and PV modules, offer greater reliability than any one of them alone because the energy supply does not depend entirely on any one source [31-34]. Figure 5 shows the schematic diagram representing the scheme as implemented in the HOMER simulation tool.

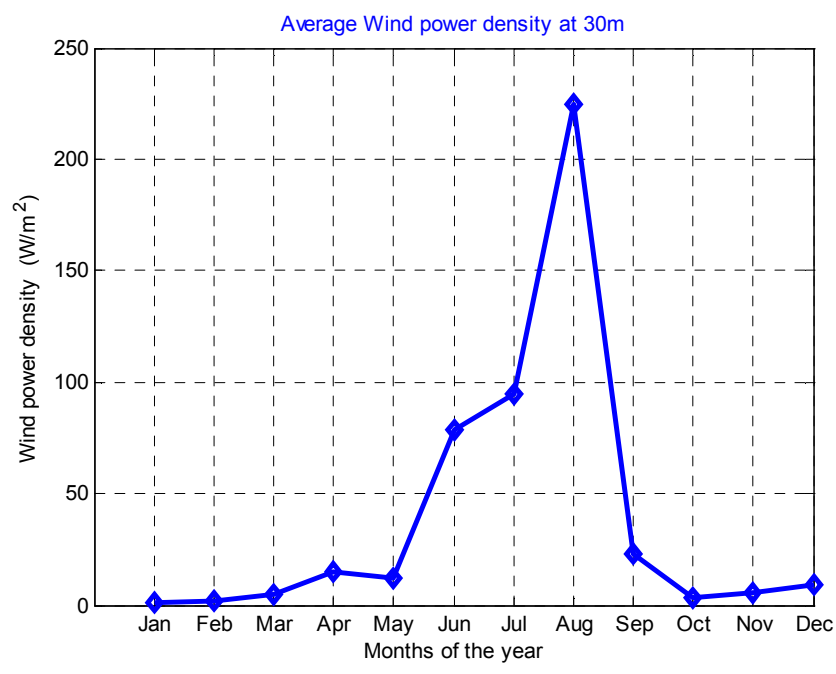

Figure 4. Average monthly wind power density at $30 \mathrm{~m}$.

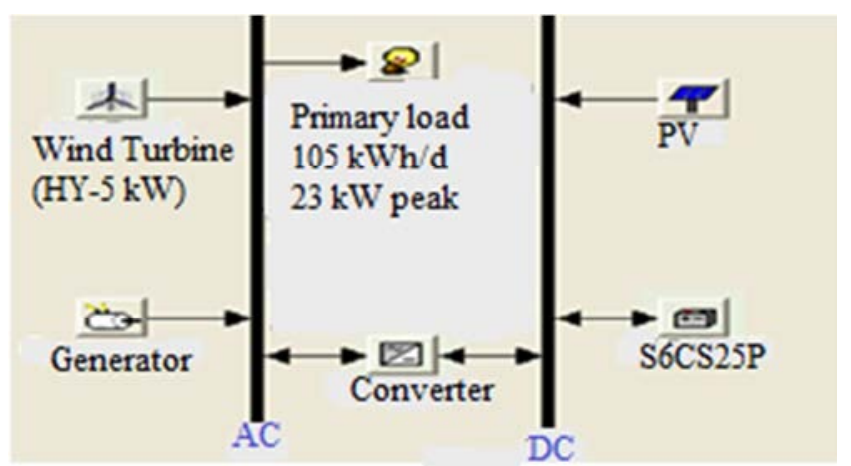

Figure 5. HOMER diagram for the hybrid system.

HOMER simulates the operation of the considered system by making energy balance calculations for each of the 8760 hours in a year. For each hour, HOMER compares the electric and thermal demand in the hour to the energy that the system can supply in that hour and calculates the flows of energy to and from each component of the system. For systems that include batteries or fuel- generators, HOMER also decides for each hour how to operate the generators and whether to charge or discharge the batteries.

HOMER performs these energy balance calculations for each system configuration under consideration. It then determines whether a configuration is feasible, i.e., whether it can meet the electrical demand under the specified conditions and estimates the cost of installing and operating the system over the lifetime of the project. The system cost calculations account for costs such as capital, replacement, operation and maintenance, fuel and interest. Information about the load, resources, economic, constraints, controls and other components used in HOMER for this case are given below:

\subsection{Performance Metrics}

In this study, total NPC, COE and RF have been considered as performance metrics to evaluate and compare different systems. The total NPC of a system is the present value of all the costs that it incurs over its lifetime, minus the present value of all the revenues that it earns over its lifetime. Costs include capital costs, replacement costs, operational and maintenance costs, fuel costs, and emissions penalties. On the other hand, COE is the average cost per $\mathrm{kWh}$ of electricity. The NPC is a more trustworthy number than the COE, therefore in this analysis, NPC has been taken as the primary metric. The RF is that portion of the system's total energy production originating from renewable power sources [5].

\subsection{Electric Load}

A typical load system (Table 1) for community which lives in Dembel village has been considered for the analysis. Monthly average hourly load demand has been given as an input to HOMER which then generates the daily and monthly load profile for a year for a community (figure. 6). It is found that for this system the Dembel communities' energy consumption is summarized in section 2.1 with a peak demand of nearly $23 \mathrm{KW}$.

(a) The daily energy consumptions of the households are calculated to be approximately $25.3 \mathrm{kWh} /$ day.

(b) The total energy daily energy demand for school is $0.264 \mathrm{kWh} /$ day.

(c) The total energy consumption of a health post calculated to be $3.48 \mathrm{kWh} /$ day.

(d) The total energy consumption of grinding mills calculated to be $74.2 \mathrm{kWh} /$ day.

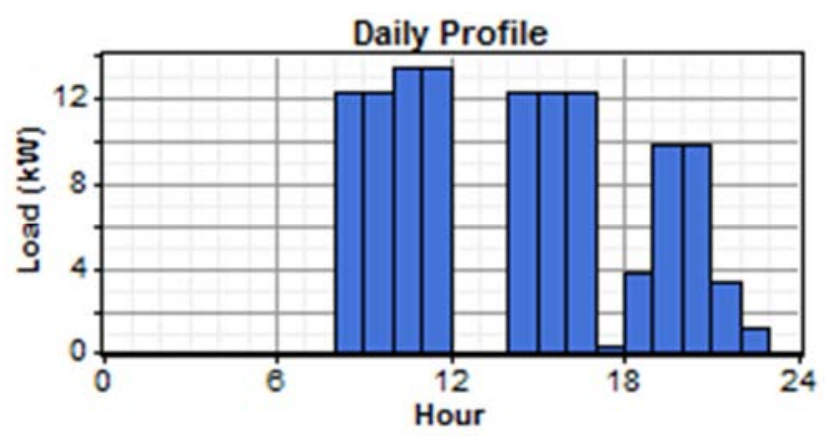

Figure 6. Daily load profile of the model village.

Figure 6 shows the time distribution of the load. Grinding machines consist of the major daily load and light bulbs are the major evening loads. The refrigerator is working all day and after 09:00 the grinding business is to reach a peak of 13 
KW. At night light bulbs, TV and radio add to the load to reach a peak of $10 \mathrm{KW}$ power.

\subsection{Renewable Resources}

The solar resource and wind speed of the desired site is estimated under section 2.2 and 2.3, respectively. HOMER provides a library of several predefined fuels, and users can add to the library if necessary $[3,8,20]$.

\subsection{Equipment to Consider}

The power sources used in the hybrid system are chosen according to the project developer's preference. For this case, wind turbines, PV, diesel generator, batteries including an energy converter with the capacity to act as both an inverter (DC to $\mathrm{AC}$ ) and a rectifier (AC to $\mathrm{DC}$ ) to help propagate energy through the entire system easily were chosen.

\subsubsection{Wind Turbine}

The primary criterion for the selection of the wind turbine is its cost. Other selection criteria used are: the type of current they generate (ac or dc), how low the cut-in wind speed is, and for what application the wind turbine be used for. The type of current they generate, whether ac or dc, is also considered as it have impacts on the size of the inverter. As the aim of the work is to supply electric energy to remotely located communities, the wind turbines selected should be those which are applicable for home or off-grid applications [8, 35-36].

Based on the selection criteria mentioned above, the type of wind turbine to be used is HY-5 KW which has a good cut- in speed of $2 \mathrm{~m} / \mathrm{s}$. This wind turbine was obtained from those wind turbine website owned by Hulk Energy Machinery. The turbine is a $5 \mathrm{~kW}$ turbine commonly available on the market such as the one for which the power curve is given in figure 7 .

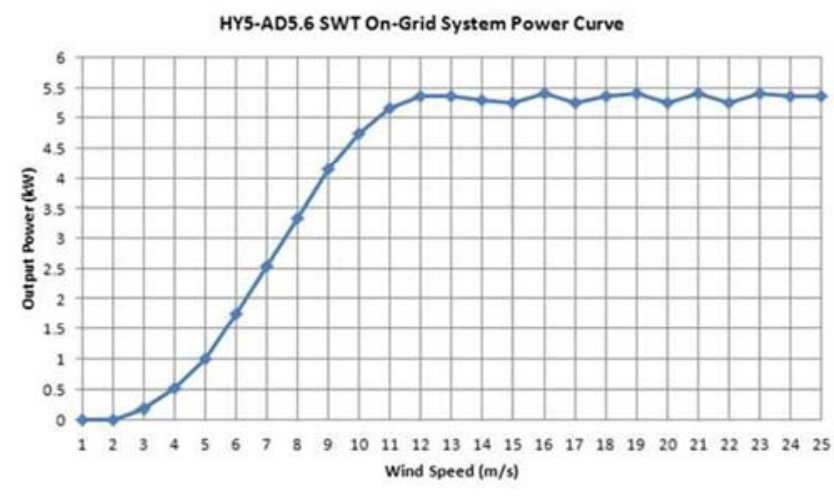

Figure 7. Power curve for HY-5 wind turbine [37].

\subsubsection{Photovoltaic (PV) Module}

In the same manner with the wind power system, HOMER has got a window where different design parameters will be fed for considering PV module in the simulation. These data include the size of PV system, the cost (capital, replacement, and O\&M), the life time, and other related design data. Sizes of PV systems have been proposed in the range of $0 \mathrm{~kW}$ to
$40 \mathrm{~kW}$ to study the sensitivity of the variation in the PV system beginning from no PV from the system to the maximum of $40 \mathrm{~kW}$. Accordingly the capital cost of each sizes have been linked to the appropriate sizes. Here it should be noted that the capital cost estimation has been taken directly from Table 2 , consequently $\$ 3 / \mathrm{W}$ of capital cost has been used as cost multiplier. In the replacement column also, a cost multiplier of $\$ 1.8 / \mathrm{W}$ has been used [15, 38-40]. In the $\mathrm{O}$ and $\mathrm{M}$ section of the input, almost the cost is negligible, therefore left to be null. Moreover the estimated life time (25 years).

\subsubsection{Diesel Generators}

The diesel generator in this hybrid system acts as the secondary power source. It is set to support the PV \& wind turbine generators when they are not producing enough electricity to meet the load. Diesel generators are cheaper to install but have higher operational costs than the wind turbines and PV therefore they are run for as few hours as possible. One diesel generator was chosen and different sizes were considered for simulation, $0,6,10,15, \& 20 \mathrm{~kW}$. This allows the software to select the most economical generator capacity for the system. The capital cost for the generator was set at $\$ 0.6 / \mathrm{W}$, cost of replacement at $\$ 0.48 / \mathrm{W}$ and $\$ 0.5 /$ hour is the operation and maintenance cost excluding fuel cost $[23,41]$.

\subsubsection{Batteries}

The batteries in a hybrid system work as reserve or back up energy. They are charged when the electricity produced in the system is greater than the load and discharged when the demand is higher than the power generated. The Surrette 6CS25P battery was chosen for this research because its financial information was available and results of its operation in a hybrid system could be accessed [3, 8, 15]. The capital cost input is assumed to cover all mounting, installation and labor costs related to the batteries' acquisition. In this case, the capital and replacement costs for one battery were $\$ 833$ and $\$ 555$ respectively while $\mathrm{O}$ and $\mathrm{M}$ costs were $\$ 15 /$ year $[3,8,15]$. The default minimum battery life for Surrette 6CS25P that is considered by HOMER is 4 years and is thus used in this study.

\subsubsection{Converter}

The converter is necessary when a power system requires the conversion of alternating current AC to direct current DC or vice versa. If both conversions are needed, the converter acts as both an inverter (DC to AC) and a rectifier (AC to DC). The capital and replacement costs for the converter were taken as $\$ 0.7 /$ watt and lifespan as 15 years $[3,8,15,20]$.

\subsubsection{Other Parameters}

The parameters in this sector help in defining how the calculations are done. They cover the Economics, System Control, Emissions and Constraints of the hybrid system. 
Table 3. Inputs to the HOMER software.

\begin{tabular}{|c|c|c|c|c|c|}
\hline & PV Module & Wind turbine & Diesel Generator & Battery S6CS25p & Converter \\
\hline Size $(\mathrm{kW})$ & 1 & 5 & 15 & 1156Ah & 1 \\
\hline Capital (\$) & $1200-4500$ & 4990 & 9000 & 833 & 700 \\
\hline Replacement Cost(\$) & $1200-4500$ & 3327 & 7200 & 555 & 700 \\
\hline$O \& M \operatorname{cost}(\$ / y r)$ & 0 & 100 & $0.5 / \mathrm{hr}$ & 15 & 0 \\
\hline Sizes $(\mathrm{kW})$ considered & $0,5,10,15,20,25,30,35,40$ & --------- & $0,6,10,15,20$ & ----------- & $0,10,15,20$ \\
\hline Quantities & -------- & $0,1,2,3$ & ---------- & $0,1,4,8,12,16,24,32$ & -------- \\
\hline
\end{tabular}

The Economics section covers interest rates and helps in the calculation of net present value. (Annual real interest rate is a term used to express the discount rate used to convert between onetime cost and annualized costs. Here in Ethiopia, the interest rate from Ethiopian National Bank is $10 \%$ and 25 years project life time is used for present cost analysis). The emissions section lets the developer calculate the amounts and consequent penalties of hazardous gases emitted by the power system. To account greenhouse effect, a $\$ 15 /$ tone of penalty for $\mathrm{CO}_{2}$ emission is considered. The constraints section allows the modeler to set operational limits in which the system is feasible. These operational limits include the maximum annual capacity shortage, renewable energy fraction, operating reserve and primary energy savings. Maximum annual energy shortage and minimum renewable fraction are set to $5 \%$ and $0 \%$ respectively [5].

\subsection{Summary of Sensitivity Cases and Optimization Variables}

Table 4 shows the Sensitivity inputs, and the Optimization Variables. A diesel price of $\$ 0.8 / 1, \$ 1.0 / 1$ and $\$ 1.2 / 1$, turbines hub height at $10 \mathrm{~m}$ and $30 \mathrm{~m}$ and a PV capital and replacement cost multipliers of $0.6,0.8$ and 1 are taken for sensitivity analysis.

Table 4. Summary of Optimization Variables and Sensitivity Inputs.

\begin{tabular}{|c|c|c|c|c|c|c|c|}
\hline \multicolumn{5}{|c|}{ Optimizations variable } & \multicolumn{3}{|c|}{ Sensitivity Inputs } \\
\hline PV (kW) & HY-5 (Quan) & Gen $(k W)$ & Batteries (Quan) & Conv (kW) & Diesel (\$/L) & $\begin{array}{l}\text { Turbines Hub } \\
\text { height (meters) }\end{array}$ & $\begin{array}{l}\text { PVcapital and replacement } \\
\text { cost multipliers }\end{array}$ \\
\hline $\begin{array}{l}0,5,10,15,20 \\
25,30,35,40\end{array}$ & $0,1,2,3$ & $\begin{array}{l}0,6,10,15 \\
20\end{array}$ & $\begin{array}{l}0,4,8,12,16,24, \\
32\end{array}$ & $0,10,15,20$ & $0.8,1,1.2$ & 10,30 & $0.6,0.8,1$ \\
\hline
\end{tabular}

\section{Results and Discussion}

After entering the wind and solar resource data into software, to find the optimum solutions, HOMER is run repeatedly by varying parameters that have a controlling effect over the output. The parameters that have controlling effect on output are given in table 3.

\subsection{Optimization Results}

The output of the simulation is a list of feasible combinations of PV, wind-turbine, generator, converter, and battery hybrid system set-up. The resulting list of optimal combinations of realizable setups obtained is given in both overall and categorized forms. The tables are generated based on a particular set of inputs selected from the input summary table (table 3 ) and the solar and wind resource data for site. Table 5 shows the resulting list of feasible combinations of system components in the overall form. As the table is too long to fit in this section, it has been truncated and only a selected part is kept here.

The following remarkable results can be noted from the table. The most cost effective system, i.e. the system with the lowest net present cost, is the PV-generator-battery-converter set-up with the generator operating. For this set-up, the total net present cost (NPC) is $\$ 155,875$, the cost of energy $(\mathrm{COE})$ is $0.415 \$ / \mathrm{kWh}$, contribution from renewable resources is $91 \%$, the amount of diesel oil used annually is 2,233 liters and the generator operates for 1,859 hours per year.

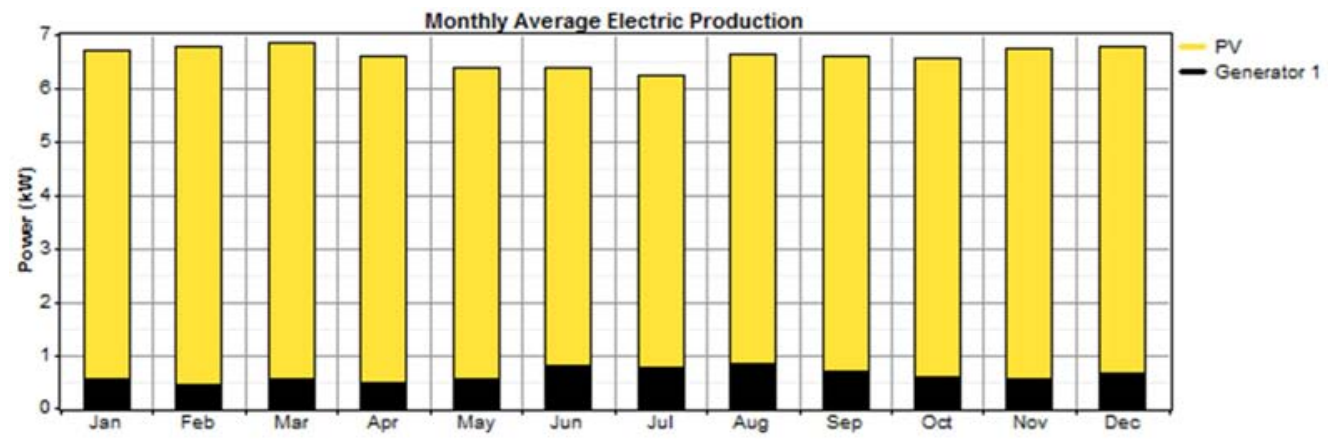

Figure 8. Contribution of the power units with $91 \% R F, 1^{\text {st }}$ row in Table 4. 
In this set-up the part that renewable resources contribute to the supply system is quite significant, being $91 \%$. This setup could be a good choice for implementation. Figure 8 shows the monthly average electrical production of this system. Table 6 gives some of the main information about the system. The cost breakdown supported by a column-chart for this set-up is also given in Figure 9.

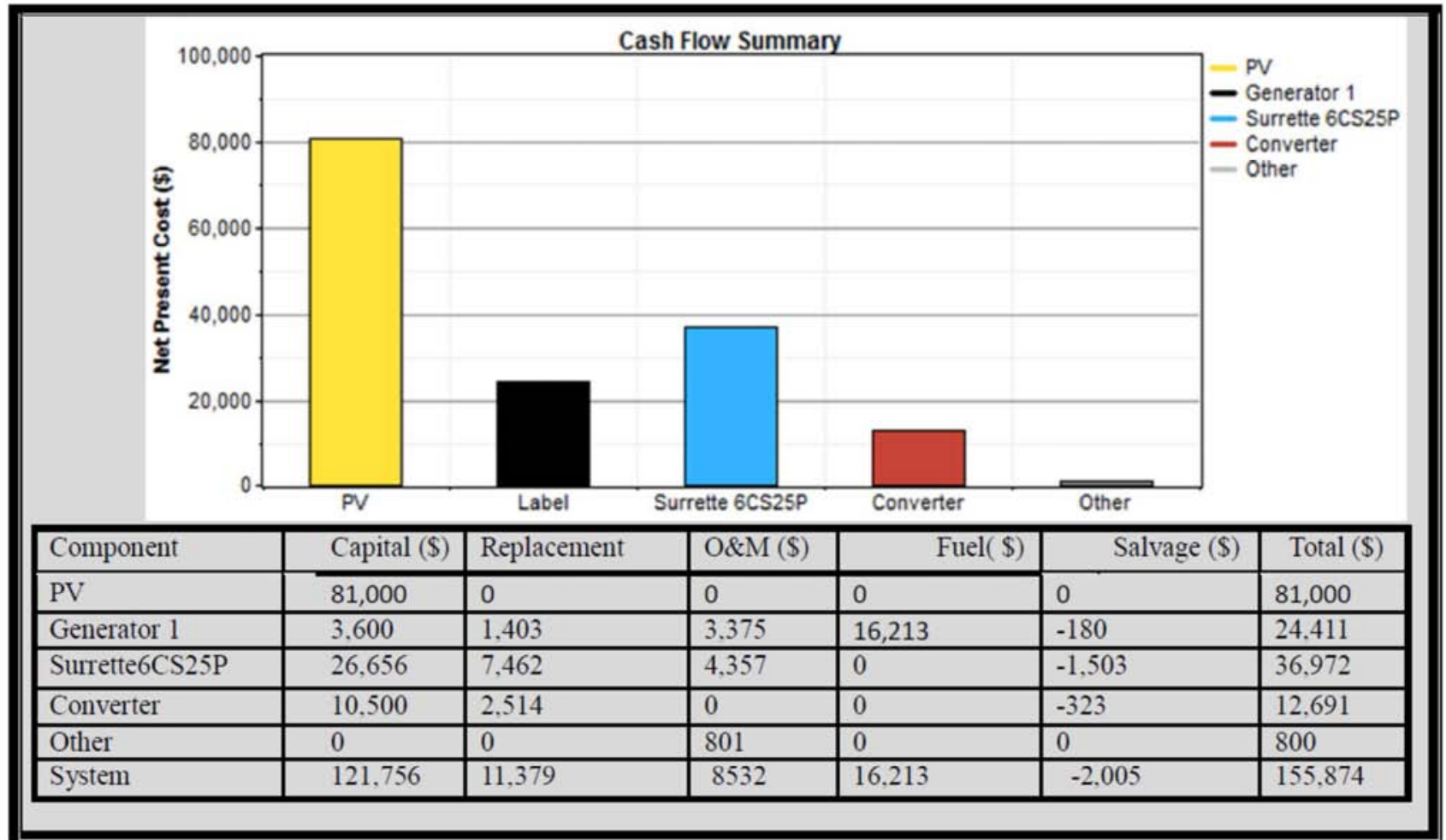

Figure 9. Cost summary for the $91 \%$ renewable resource contribution.

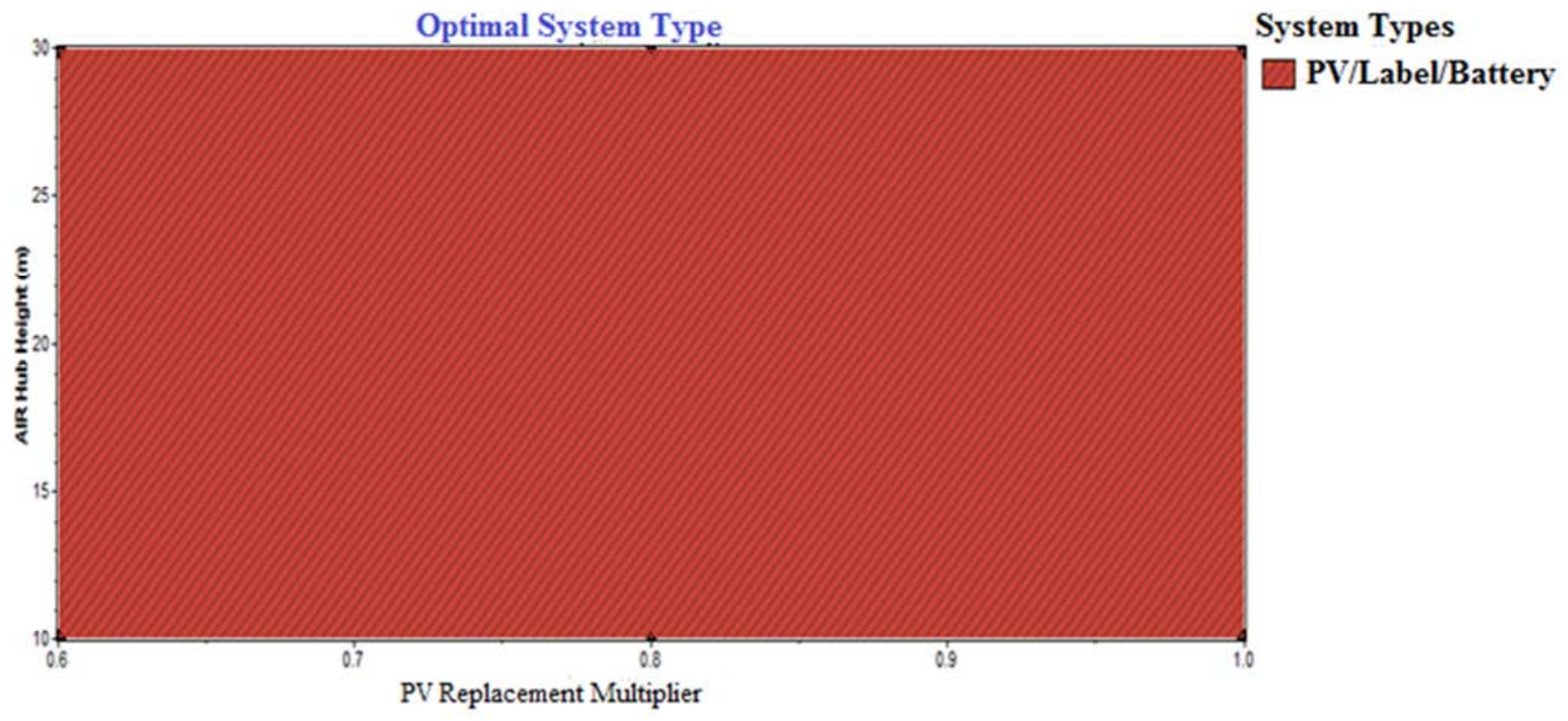

Figure 10. Sensitivity of $P V$ cost to diesel price with some important NPCs labeled. 
Table 5. Overall optimization results.

\begin{tabular}{|c|c|c|c|c|c|c|c|c|c|c|c|c|c|}
\hline PV (kW) & HY-5 & Gen.(kW) & Battery & $\begin{array}{l}\text { Converter } \\
(\mathrm{kW})\end{array}$ & $\begin{array}{l}\text { Dispatch } \\
\text { strategy }\end{array}$ & $\begin{array}{l}\text { Initial } \\
\text { capital }\end{array}$ & $\begin{array}{l}\text { Operating } \\
\operatorname{cost}(\$ / y)\end{array}$ & Total NPC & $\begin{array}{l}\text { COE } \\
(\$ / k W h)\end{array}$ & $\begin{array}{l}\text { Renewable } \\
\text { fraction }\end{array}$ & $\begin{array}{l}\text { Capacity } \\
\text { shortage }\end{array}$ & $\begin{array}{l}\text { Diesel } \\
\text { (L) }\end{array}$ & Gen.(hrs) \\
\hline 30 & & 6 & 32 & 15 & LF & $\$ 121,756$ & 3,759 & $\$ 155,875$ & 0.415 & 0.91 & 0.04 & 2,233 & 1,859 \\
\hline 30 & & 6 & 32 & 20 & LF & $\$ 125,256$ & 3,408 & $\$ 156,190$ & 0.419 & 0.92 & 0.05 & 1,885 & 1,443 \\
\hline 35 & & 6 & 24 & 20 & LF & $\$ 132,092$ & 2,774 & $\$ 157,272$ & 0.419 & 0.94 & 0.03 & 1,555 & 1,213 \\
\hline 35 & & 6 & 24 & 15 & LF & $\$ 128,592$ & 3,237 & $\$ 157,975$ & 0.419 & 0.93 & 0.03 & 2,012 & 1,707 \\
\hline 20 & & 6 & 16 & 10 & $\mathrm{CC}$ & $\$ 77,928$ & 9,000 & $\$ 159,624$ & 0.422 & 0.61 & 0.03 & 8,007 & 4,879 \\
\hline 20 & & 10 & 8 & 15 & LF & $\$ 77,164$ & 9,135 & $\$ 160,080$ & 0.426 & 0.64 & 0.05 & 7,917 & 3,812 \\
\hline 20 & & 10 & 8 & 10 & LF & $\$ 73,664$ & 9,540 & $\$ 160,263$ & 0.425 & 0.63 & 0.04 & 8,347 & 4,031 \\
\hline 20 & & 10 & 12 & 15 & LF & $\$ 80,496$ & 8,846 & $\$ 160,787$ & 0.427 & 0.66 & 0.05 & 7,514 & 3,650 \\
\hline 35 & & 6 & 32 & 20 & LF & $\$ 138,756$ & 2,431 & $\$ 160,822$ & 0.424 & 0.96 & 0.02 & 978 & 765 \\
\hline 25 & & 10 & 16 & 15 & LF & $\$ 97,328$ & 7,003 & $\$ 160,894$ & 0.424 & 0.76 & 0.03 & 5,674 & 2,887 \\
\hline 20 & & 10 & 12 & 10 & LF & \$ 76,996 & 9,248 & $\$ 160,942$ & 0.426 & 0.64 & 0.04 & 7,927 & 3,889 \\
\hline 25 & & 10 & 12 & 15 & LF & $\$ 93,996$ & 7,382 & $\$ 161,001$ & 0.425 & 0.75 & 0.03 & 6,148 & 3,105 \\
\hline 30 & 1 & 6 & 32 & 15 & LF & $\$ 126,746$ & 3,859 & $\$ 161,771$ & 0.431 & 0.91 & 0.04 & 2,233 & 1,859 \\
\hline 25 & & 10 & 8 & 15 & LF & $\$ 90,664$ & 7,847 & $\$ 161,888$ & 0.428 & 0.73 & 0.03 & 6,703 & 3,348 \\
\hline 40 & & & 32 & 20 & $\mathrm{CC}$ & $\$ 148,656$ & 1,458 & $\$ 161,893$ & 0.436 & 1.00 & 0.04 & & \\
\hline 40 & & & 32 & 20 & LF & $\$ 148,656$ & 1,458 & $\$ 161,893$ & 0.436 & 1.00 & 0.04 & & \\
\hline 20 & & 10 & 16 & 15 & LF & $\$ 83,828$ & 8,620 & $\$ 162,070$ & 0.430 & 0.67 & 0.04 & 7,178 & 3,503 \\
\hline 30 & 1 & 6 & 32 & 20 & LF & $\$ 130,246$ & 3,507 & $\$ 162,076$ & 0.435 & 0.92 & 0.05 & 1,883 & 1,442 \\
\hline 20 & & 10 & 16 & 10 & LF & $\$ 80,328$ & 9,018 & $\$ 162,186$ & 0.429 & 0.66 & 0.03 & 7,573 & 3,757 \\
\hline 25 & & 10 & 16 & 20 & LF & $\$ 100,828$ & 6,762 & $\$ 162,206$ & 0.428 & 0.77 & 0.03 & 5,431 & 2,684 \\
\hline 35 & & 6 & 32 & 15 & LF & $\$ 135,256$ & 2,990 & $\$ 162,394$ & 0.427 & 0.95 & 0.02 & 1,518 & 1,348 \\
\hline
\end{tabular}

Table 6. System report for the $91 \%$ renewable resource contribution.

\begin{tabular}{|c|c|c|c|c|c|c|}
\hline \multicolumn{4}{|c|}{ System Architecture } & \multicolumn{3}{|c|}{ Annual Electric Production(kWh/yr) } \\
\hline PV Array & $30 \mathrm{KW}$ & Sensitivity case & & PV Array & 52,479 & $91 \%$ \\
\hline Wind Turbine & 0 & Solar Data $\left(\mathrm{kWh} / \mathrm{m}^{2} / \mathrm{d}\right)$ & 5.9 & Wind Turbine & 0 & $0 \%$ \\
\hline Gen1 & $6 \mathrm{KW}$ & Wind $(\mathrm{m} / \mathrm{s})$ & 1.1 & Gen 1 & 5,361 & $9 \%$ \\
\hline Battery & 32 Surret6CS25 & Diesel Price $(\$ / L)$ : & 1 & Total & 57,840 & $100 \%$ \\
\hline Inverter & $15 \mathrm{KW}$ & PV Capital Cost Multiplier: & 1 & Excess electricity & 9,380 & 16.2 \\
\hline Rectifier & $15 \mathrm{KW}$ & PV Repl. Cost Multiplier: & 0.6 & Unmet load & 990 & 2.3 \\
\hline Dispatch Strategy & Load Following & & & Capacity shortage & 1,576 & 3.7 \\
\hline
\end{tabular}

Table 6. Continued.

\begin{tabular}{|c|c|c|c|c|c|c|c|c|}
\hline \multicolumn{4}{|c|}{ System Architecture } & \multicolumn{3}{|c|}{$\begin{array}{l}\text { Annual Electric consumption } \\
(\mathbf{k W h} / \mathbf{y r})\end{array}$} & \multicolumn{2}{|l|}{ Emissions } \\
\hline PV Array & $30 \mathrm{KW}$ & Sensitivity case & & $\begin{array}{l}\text { AC primary } \\
\text { load }\end{array}$ & 41,350 & $100 \%$ & Pollutant & $\begin{array}{l}\text { Emissions } \\
(\mathrm{kg} / \mathrm{yr})\end{array}$ \\
\hline Wind Turbine & 0 & Solar Data $\left(\mathrm{kWh} / \mathrm{m}^{2} / \mathrm{d}\right)$ & 5.9 & Total & 41,350 & $100 \%$ & $\mathrm{CO}_{2}$ & 5,879 \\
\hline Gen 1 & $6 \mathrm{KW}$ & Wind $(\mathrm{m} / \mathrm{s})$ & 1.1 & & & & $\mathrm{CO}$ & 14.5 \\
\hline Battery & 32 Surret6CS25 & Diesel Price $(\$ / L)$ : & 1 & Cost summary & & & Unburned $\mathrm{HC}$ & 1.61 \\
\hline Inverter & $15 \mathrm{KW}$ & PV Capital Cost Multiplier: & 1 & Total NPC & \multicolumn{2}{|l|}{$\$ 155,875$} & $\begin{array}{l}\text { Particulate } \\
\text { matter }\end{array}$ & 1.09 \\
\hline Rectifier & $15 \mathrm{KW}$ & PV Repl. Cost Multiplier: & 0.6 & Levelized CoE & \multicolumn{2}{|c|}{$\$ 0.415 / \mathrm{KWh}$} & $\mathrm{SO}_{2}$ & 11.8 \\
\hline Dispatch Strategy & Load Following & & & Operating cost & $\$ 3,759$ & & $\mathrm{NO}_{\mathrm{x}}$ & 129 \\
\hline
\end{tabular}

\subsection{Sensitivity Result}

Sensitivity analysis was also carried out and figure 10 shows the variation of PV capital cost multiplier against diesel price for a fixed average wind speed of $1.1 \mathrm{~m} / \mathrm{s}$ (measured at 2 meters) and average solar radiation of 5.9 $\mathrm{kWh} / \mathrm{m}^{2} /$ day. In the figure, the net present cost of the most cost-effective set-up for a particular set of diesel and PV prices is also included. In this figure (fig.10) it can be seen that the wind plays no role in supplying energy to the community.

\section{Conclusion}

The study aimed at estimating wind and solar resource potential, identifying options and designing of hybrid energy system to supply electricity for Dembel district in Somali region- Ethiopia which equipped with a health clinic and school to improve the life of these rural community, which are not electrify via main grid yet. Techno economic analysis of this option has been done and hybrid PV-generator-battery-converter set-up system became economically feasible for the proposed site. From 
the results, the wind energy potential of the site is found to be considerable very low and the area has huge utilizable solar energy potential. HOMER simulation program developed by NREL has been used as optimization and simulation tool and the result was analyzed and the PVgenerator-battery-converter hybrid system was selected among the many feasible systems based on some important parameters such as less net present cost, high renewable penetration, small levelized cost of energy, less annual diesel consumption, less unmet load, and less capacity shortage. The COE of the feasible setup in this study is $0.415 \$ / \mathrm{kWh}$, which is high compared to the current global electricity tariff and the tariff in the country $(<5$ cents $/ \mathrm{kWh})$. However, considering the shortage of electricity in the country $(<20 \%$ coverage $)$ and absence of electricity usage in rural areas $(<2 \%$ coverage $)$, this cost should not be taken as a decisive factor. Taking these issues into account the free solar and wind energy of the country should be utilized to improve the quality of life of the communities living in rural areas.

\section{Acknowledgments}

I would like to acknowledge Jijiga University for sponsorship and National meteorological agency of Ethiopia (NMA) for the meteorological data they have supplied to me. The comments and suggestions provided by the Mr Asnake Sahele, Dr. Yedilfana Setarge and Dr. Girum Ayalneh are highly appreciated and duly acknowledged.

\section{References}

[1] C. Breyer et al., "ELECTRIFYING THE POOR: HIGHLY ECONOMIC OFF-GRID PV SYSTEMS IN ETHIOPIA - A BASIS FOR SUSTAINABLE RURAL DEVELOPMENT," 2007.

[2] "CIA the world fact book," 2010. [Online]. Available: http://www.umsl.edu/services/govdocs/wofact2007/geos/et.ht ml\#People. [Accessed: 01-Jan-2001].

[3] B. Getachew, "STUDY INTO THE POTENTIAL AND FEASIBILITY OF A STANDALONE SOLAR- WIND HYBRID ELECTRIC ENERGY SUPPLY For Application in Ethiopia.," Royal Institute of Technology KTH, Doctoral Thesis, 2009.

[4] A. Dalelo, "RURAL ELECTRIFICATION IN ETHIOPIA" Addis Ababa Univ. Coll. Educ. Dep. Geogr. Environ. Educ., 2003.

[5] HOMER, "The micropower optimization model, ver.2.81Beta." [Online]. Available: http://www.nrel.gov/homer.

[6] Japanese Embassy in Ethiopia, "Study on the Energy Sector in Ethiopia," 2008.

[7] A. Gupta, R. P. Saini, and M. P. Sharma, "Modelling of hybrid energy system d Part I: Problem formulation and model development," Renew. Energy, vol. 36, no. 2, pp. 459-465, 2011.

[8] G. Boneya, "Design of a Photovoltaic-Wind Hybrid Power
Generation System for Ethiopian Remote Area," Addis Ababa University, Institute of Technology, Department of Electrical and Computer Engineering, MSc. Thesis, 2011.

[9] J. A. Duffie and W. A. Beckman, Solar Engineering of Thermal Processes, Fourth Edi. New York: Wiley.

[10] A. Usman, M. Akhtar, and K. Jamil, "Empirical Models for the Estimation of Global Solar Radiation with Sunshine Hours on Horizontal Surface in Various Cities of Pakistan," Pakistain J. Meteorol., vol. 9, no. 18, pp. 43-49, 2013.

[11] P. Gipe, Wind Power: Renewable Energy for Home, Farm, and Business. Chelsea Green Publishing Company., 2004.

[12] A. V. da Rosa, Fundamentals of Renewable Energy processes. Elsevier Inc, 2005.

[13] M. R. Patel, Wind and Solar Power Systems: Design, Analysis, and Operation, Edition, S. Taylor \& Francis Group, 2006.

[14] J. Twidell and T. Weir, Renewable Energy Resources, 2nd Edn. London: Taylor \& Francis, 2006.

[15] R. Chemeda, "ROYAL INSITITUTE OF TECHNOLOGY FEASIBILITY STUDY OF STAND ALONE WIND-SOLAR PV HYBRID ENERGY SYSTEMS FOR SMALL.," ROYAL INSITITUTE OF TECHNOLOGY KTH, MSc. Thesis Final Report, 2009.

[16] A. H. Abraha, M. B. Kahsay, and C. Z. M. Kimambo, "Hybrid Solar - Wind - Diesel Systems for Rural Application in North Ethiopia: Case Study for Three Rural Villages using HOMER Simulation," Momona Ethiop. J. Sci., vol. 5, no. 2, pp. 62-80.

[17] S. Pradeepkumar, P. Azhagiri, T. Senthilkumar, and B. Kumaragurubaran, "Generation of Electrical Energy Using Hybrid Energy of PV Solar Cell, Wind Turbine, Rain Water and Perpetual Motion," Imp. J. Interdiscip. Res., vol. 2, no. 6, pp. 1512-1521, 2016.

[18] S. T. Bahta, "Design and Analyzing of an Off-Grid Hybrid Renewable Energy System to Supply Electricity for Rural Areas," KTH Royal Institute of Technology, Master of Science Thesis, 2013.

[19] N. A. Bila, "Feasibility Study of Solar-Wind Hybrid Power System for Rural Electrification at the Estatuene Locality in Mozambique," KTH Royal Institute of Technology, Master of Science Thesis, 2015.

[20] G. Tadesse, "Feasibility Study of Small Hydro / PV / Wind Hybrid System ystem for Off Off-Grid Grid Rural Electrification in Ethiopia.," Addis Ababa University, Institute of Technology, Department of Electrical and Computer Engineering, MSc. Thesis, 2011.

[21] A. Mohajer, O. Nematollahi, M. M. Joybari, S. A. Hashemi, and M. R. Assari, "Experimental investigation of a Hybrid Solar Drier and Water Heater System," Energy Convers. Manag., vol. 76, pp. 935-944, 2013.

[22] B. Moges and A. Retta, "ROYAL INSITITUTE OF TECHNOLOGY MODELING AND ANALYSIS OF WIND HYDROGEN ENERGY Msc thesis final report," ROYAL INSITITUTE OF TECHNOLOGY KTH, MSc. Thesis, 2010.

[23] C. Arthur, O. Supervisor, and B. Uzunoglu, "Hybrid Energy System for Off - Grid Rural Electrification ( Case study Kenya )," MSC WIND POWER PROJECT MANAGEMENT, GOTLAND UNIVERSITY Hybrid, 2011. 
[24] R. K. Akikur, R. Saidur, H. W. Ping, and K. R. Ullah, "Comparative study of stand-alone and hybrid solar energy systems suitable for off-grid rural electri fi cation: A review," Renew. Sustain. Energy Rev., vol. 27, pp. 738-752, 2013.

[25] A. S. Tiwari, "Solar and Wind Hybrid System for Rural Electrification," Int. J. Recent Innov. Trends Comput. Commun., vol. 2, no. 5, pp. 1074-1077, 2014.

[26] A. González, J. R. Riba, and A. Rius, "Optimal sizing of a hybrid grid-connected photovoltaic-wind-biomass power system," Sustain., vol. 7, no. 9, pp. 12787-12806, 2015.

[27] A. M. Yebi, "Techno-economic Assessment of Wind Energy to Supply the Demand of Electricity for a Residential Community in Ethiopia.," YAL INSITITUTE OF TECHNOLOGY KTH, MSc. Thesis, 2011.

[28] I. Tzanakis, "COMBINING WIND AND SOLAR ENERGY TO MEET DEMANDS IN THE BUILT ENVIRONMENT (GLASGOW-HERAKLION CRETE ANALYSIS)," University of Strathclyde, MSc in Energy Systems and the Environment, 2006.

[29] Natei Ermias Benti, "FEASIBILITY STUDY OF STAND ALONE WIND-SOLAR PHOTOVOLTAIC (PV) HYBRID ENERGY SYSTEMS FOR ELECTRIFICATION FOR RURAL ETHIOPIA (A CASE STUDY HADAS VILLAGE)," Haramaya University, CNCS, Department of Physics, MSc. Thesis, 2012.

[30] B. Ali, K. Sopian, M. A. Rahman, M. Y. Othman, A. Zaharim, and A. M. Razali, "Performance of a Hybrid Photovoltaic Diesel System in a Cable Car Resort Facility," in 4th IASME/WSEAS International Conference on ENERGY, ENVIRONMENT, ECOSYSTEMS and SUSTAINABLE DEVELOPMENT (EEESD'08), 2008, pp. 183-187.

[31] G. C. Bakos, "Feasibility study of a hybrid wind / hydro power-system for low-cost electricity production," Elsevier Appl. Energy, vol. 72, pp. 599-608, 2002.
[32] D. Connolly, H. Lund, B. V Mathiesen, and M. Leahy, "A review of computer tools for analysing the integration of renewable energy into various energy systems," Appl. Energy, vol. 87, no. 4, pp. 1059-1082, 2010.

[33] R. P. Saini and M. P. Sharma, "Integrated renewable energy systems for off grid rural electrification of remote area," Renew. Energy, vol. 35, no. 6, pp. 1342-1349, 2010.

[34] T. Ma, H. Yang, and L. Lu, "A feasibility study of a standalone hybrid solar - wind - battery system for a remote island for a remote island," Appl. Energy, vol. 121, no. May 2014, pp. 149-158, 2015.

[35] "All Small Wind Turbines website." [Online]. Available: http://www.allsmallwindturbines.com/. [Accessed: 20-Feb2016].

[36] "HUAYING Wind Turbine:" [Online]. Available: http://www.huayingwindpower.com/. [Accessed: 19-Feb2016].

[37] "Hulk Energy Machinery." [Online]. Available: http://www.hulkenergy.com. [Accessed: 20-Feb-2016].

[38] "Eco Business Links,." [Online]. Available: http://www.ecobusinesslinks.com. [Accessed: 20-Feb-2016].

[39] "Solar buzz." [Online]. Available: http://www.solarbuzz.com/industry-news. [Accessed: 22-Feb2016].

[40] "Solar Panel Price." [Online]. Available: http://solarpanelprices.org. [Accessed: 22-Feb-2016].

[41] “Cummins Diesel Generator Data Sheet." [Online]. Available: $\mathrm{http}: / /$ www.rieanpishroco.com/cummins. [Accessed: 24-Feb2016]. 